\title{
Game of Attitudes: educational gerontotechnology for the elderly undergoing haemodialysis
}

\author{
Jogo das Atitudes: gerontotecnologia educacional para idosos em tratamento hemodialítico \\ Juego de actitudes: gerontotecnología educacional para ancianos en tratamiento hemodialítico
}

\section{Danieley Cristini Lucca' \\ ORCID: 0000-0002-2072-9742}

Karina Silveira de Almeida Hammerschmidt" ORCID: 0000-0002-7140-3427

Juliana Balbinot Reis Girondi' ORCID: 0000-0003-0271-259X

Darla Lusia Ropelato Fernandez ORCID: 0000-0002-6137-7659

Anderson Abreu de Carvalho' ORCID: 0000-0002-4355-1721

Suzana dos Santos Rosa' ORCID: 0000-0002-0720-5928

Bianca Martins Dacoregio' ORCID: 0000-0002-4574-2759

'Universidade Federal de Santa Catarina. Florianópolis, Santa Catarina, Brazil.

"Universidade Federal do Paraná. Curitiba, Paraná, Brazil.

How to cite this article:

Lucca DC, Hammerschmidt KSA, Girondi JBR, Fernandez DLR, Carvalho AA, Rosa SS, Dacoregio BM. Game of attitudes: Educational gerontotechnology for the elderly undergoing hemodialysis. Rev Bras Enferm. 2020;73(Suppl 3):e20180694. doi: http://dx.doi.org/ 10.1590/0034-7167-2018-0694

\section{Corresponding author: \\ Danieley Cristini Lucca \\ E-mail: danylucca.enf@gmail.com}

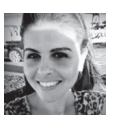

EDITOR IN CHIEF: Dulce Barbosa ASSOCIATE EDITOR: Marcia Magro

Submission: 10-10-2018

Approval: 04-27-2020

\begin{abstract}
Objective: To develop and apply educational gerontotechnology through the articulation of playfulness, aimed at promoting the health of the elderly undergoing haemodialysis. Method: Convergent Care Research, following phases: conception, research structure (problem, objective and literature review); instrumentation, involving decisions about delimitation/ detailing of the location (haemodialysis clinic), participants (ten elderly patients on haemodialysis), data collection instruments (semi-structured interview, participant observation and documentary/medical analysis); screening, rigorous investigation of haemodialysis treatment and analysis, guided by apprehension, synthesis, theorization and transfer. Results: Health needs of emerging elderly: Complications and worsening of chronic kidney disease; Self-care; Empowerment; Deficit of activities; Health promotion and Nursing care; and Importance of the family. Gerontotechnology developed: Game of Attitudes; its application aroused feelings - overcoming, occupation and knowledge. Final considerations: Game of attitudes makes it possible to remodel the care of the elderly undergoing haemodialysis; it is a tool that enriches the practice, allows innovation, aiding in the success of the treatment. Descriptors: Elderly; Chronic Renal Insufficiency; Renal Dialysis; Health Promotion; Educational Technology.
\end{abstract}

\section{RESUMO}

Objetivo: Desenvolver e aplicar gerontotecnologia educacional por meio da articulação do lúdico, visando à promoção da saúde dos idosos em tratamento hemodialítico. Método: Pesquisa Convergente Assistencial, seguindo fases: concepção, estruturação da pesquisa (problema, objetivo e revisão de literatura); instrumentação, envolvendo decisões sobre delimitação/detalhamento do local (clínica de hemodiálise), participantes (dez idosos em hemodiálise), instrumentos coleta de dados (entrevista semiestruturada, observação participante e análise documental/prontuários); perscrutação, investigação rigorosa sobre tratamento hemodialítico e análise, guiada pela apreensão, síntese, teorização e transferência. Resultados: Necessidades de saúde dos idosos emergentes: Complicações e agravos da doença renal crônica; Autocuidado; Empoderamento; Déficit de atividades; Promoção da saúde e o cuidado de Enfermagem; e Importância da família. Gerontotecnologia desenvolvida: Jogo das Atitudes; sua aplicação suscitou sentimentos - superação, ocupação e conhecimento. Considerações finais: Jogo das atitudes possibilita remodelar o cuidado dos idosos em tratamento hemodialítico; é ferramenta que enriquece a prática, permite inovação, auxiliando no sucesso do tratamento.

Descritores: Idoso; Insuficiência Renal Crônica; Diálise Renal; Promoção da Saúde; Tecnologia Educacional.

\section{RESUMEN}

Objetivo: Desarrollar y aplicar gerontotecnología educacional por medio de la articulación del lúdico, con vistas a la promoción de la salud de los ancianos en tratamiento hemodialítico. Método: Investigación Convergente Asistencial, siguiendo fases: concepción, estructuración de la investigación (problema, objetivo y revisión de literatura); instrumentación, envolviendo decisiones sobre delimitación/caracterización del local (clínica de hemodiálisis), participantes (diez ancianos en hemodiálisis), instrumentos recogida de datos (entrevista semiestructurada, observación participante y análisis documental/prontuarios); perscrutación investigación rigorosa sobre tratamiento hemodialítico y análisis, guiado por la aprehensión, síntesis, teorización y transferencia. Resultados: Necesidades de salud de los ancianos emergentes: Complicaciones y agravios de la enfermedad renal crónica; Autocuidado; Empoderamiento; Déficit de actividades; Promoción de la salud y el cuidado de Enfermería; e Importancia de la familia. Gerontotecnología desarrollada: Juego de Actitudes; su aplicación suscitó sentimientos - superación, ocupación y conocimiento. Consideraciones finales: Juego de actitudes posibilita remodelar el cuidado de los ancianos en tratamiento hemodialítico; es herramienta que enriquece la práctica, permite innovación, auxiliando en el suceso del tratamiento.

Descriptores: Anciano; Insuficiencia Renal Crónica; Diálisis Renal; Promoción de la Salud; Tecnología Educacional. 


\section{INTRODUCTION}

The change in the demographic pattern is related to the reduction in the population growth rate and to profound transformations in the age pyramid of the Brazilian population, a consequence of the rapid and continuous fall in fertility in the country, as well as the reduction of mortality at all ages ${ }^{(1)}$.

With the increase of elderly people in the country, there is a demand for special attention to Chronic Non-communicable Diseases (NCDs) ${ }^{(2)}$. Among the chronic pathologies that most affect the world and Brazilian population, is chronic renal failure (CRF). This disease changes the subject's life and interferes with his quality of life; it is also characterized as a social problem, as it compromises the performance of the elderly in society, as their routine is completely transformed, making it necessary to remodel their daily lives ${ }^{(3)}$.

In developed countries, screening estimates a prevalence of chronic kidney disease (CKD) between 10\% and 13\% in the adult population ${ }^{(4-5)}$. In developing countries, prevalence data are limited and heterogeneous ${ }^{(6-7)}$. In Brazil, estimates of the prevalence of this disease are uncertain, however, their knowledge would support improvements in the planning of preventive and care actions ${ }^{(8)}$.

Along with the changes imposed by the disease, there are also those derived from haemodialysis treatment, which causes several contributing factors to the low quality of life of the elderly, including physical, psychological and socio-cultural factors. The limitations resulting from the treatment tend to increase with aging, generating a greater possibility of the involvement of multiple comorbidities ${ }^{(9)}$.

Haemodialysis imposes on the individual a lasting routine, making them stay on average three hours, three times a week, performing the treatment. Thus, health promotion for them runs through the care provided directly to the person undergoing haemodialysis, involves aspects of living in a macro-holistic way ${ }^{(10)}$.

Promote health in accordance with the principles of the Ottawa Charter ${ }^{(11)}$ is to enable the community to act to improve the quality of life and health, including it in the participation and control of this process. This proposal converges with the National Health Promotion Policy, in the broader perspective of health, as defined within the scope of the Brazilian Health Reform movement, the Unified Health System (SUS) and the Health Promotion Letters, proposing that the ways in which subjects and societies choose certain living options organize their choices and create new possibilities to satisfy their needs, desires and interests belonging to the collective order, enabling their construction process in the context of their own lives ${ }^{(12)}$.

In this sense, health promotion stimulated through educational gerontotechnology emerges as a proposal to help care for these people. Educational technology in nursing care can develop new forms of care that help professionals, as well as the elderly in self-care and skills development ${ }^{(13)}$.

Educational gerontotechnologies cover an interdisciplinary scope and are based on the scientific study of the aging process for the development of techniques, products and services aimed at the field of gerontology, aiming to favor the optimized living of the elderly and contemplating their biopsychological and social aspects ${ }^{(14)}$. With this, these technologies must be developed meeting the needs and specificities presented by the elderly, as they are tools that contribute to the strengthening of the potential for self-care of the elderly and allow the acquisition of knowledge, empowering them in the process of change ${ }^{(15)}$.

Nursing actions aimed at health education enable nurses to enjoy options to intervene in the promotion of patients' health ${ }^{(16)}$. The relationship between nurses and the elderly must go beyond techniques. Professionals must exercise and adopt active methodologies in care, centralizing the elderly as the protagonist of the process of (re)building their care. In this sense, recognizing the health needs of these subjects for the development of educational technology becomes essential for the immersion of this proposal in the context of health care.

\section{OBJECTIVE}

To develop and apply educational gerontotechnology through the articulation of playfulness, aiming at promoting the health of the elderly undergoing haemodialysis.

\section{METHODS}

\section{Ethical aspects}

The present study followed the guidelines and regulatory norms for research with human beings established in Resolution $466 / 2012$ of the National Health Council. An opinion was issued by the Ethics and Research Committee of the Federal University of Santa Catarina.

\section{Study type and theoretical-methodological framework}

The adopted methodology was the Convergent Care Research $(P C A)^{(17)}$, with a qualitative approach. The PCA proposes the convergence between research and assistance. This is research inserted in the care practice of nursing care for the elderly undergoing haemodialysis, with the objective of enabling a change in the practice in haemodialysis care through the insertion of educational gerontotechnology.

\section{Methodological procedures}

The methodological itinerary followed the procedures outlined by the PCA: conception, instrumentation, screening and analysis.

Conception phase - At this stage, the entire research was structured through technical visits at the institution of haemodialysis treatment, allowing definition of the problem and research objective. With the identification of the research question, a literature review was carried out in order to build the theoretical framework to support the study's relevance. The development of the synthesis of knowledge in relation to the research topic makes it possible to master the research problem through reflections involving literature reviews ${ }^{(17)}$.

Instrumentation phase - It involved decisions about the delimitation/detailing of the physical space of the research (haemodialysis clinic), choice of participants (elderly people undergoing haemodialysis) and the instruments of data collection (semi-structured interview, participant observation and 
documentary analysis/medical records). As for the physical space, although it was already decided in the previous phase, it was at this moment that the description was detailed ${ }^{(17)}$.

Peering and analysis phase - The peering phase is also present in the instrumentation phase, in addition to the analysis phase ${ }^{(17)}$. Thus, it was characterized by the entry of researchers into the reality of care practice through rigorous investigation of haemodialysis treatment, with a view to identifying the real intentions of professionals in relation to gerontotechnology. This phase used semi-structured interviews and conversation, participant unsystematic observation and document analysis (medical records). The analysis was guided by the phases of apprehension, synthesis, theorization and transfer. To understand, PCA peering occurs when information requires more properties to make changes ${ }^{(17)}$.

The development of educational gerontotechnology emerged from the health needs of the elderly undergoing haemodialysis. After the development and application of educational gerontotechnology, an evaluative instrument was used with the elderly, with questions focused on patients' feelings before and after the application of the game, for recurrent learning and experience. Through the instrument, sought to analyze the contributions of the insertion of this activity to the elderly during the haemodialysis session, aiming at the possibility of changes to the care practice.

\section{Study scenario}

The present research took place in a Haemodialysis Treatment Clinic located in the Greater Florianópolis region.

\section{Data source}

The participants in this study were elderly individuals, male and/ or female, who underwent haemodialysis treatment at least three times a week, belonging to the group that performed sessions on Mondays, Wednesdays and Fridays, in the second and third periods (10 am and $1 \mathrm{pm}$ ); the choice of time and shifts was for convenience. For the selection of the elderly, a previous contact was made with the nurse coordinating the sector, which provided a list of 18 elderly people who were undergoing treatment in the period. However, two elderly women had visual impairment, one died, three changed the period and shift of haemodialysis sessions, one was hospitalized, and one did not accept to participate in the research, resulting in ten elderly participants.

\section{Data collection and organization}

Data collection took place through the triangulation of data production techniques, that is, the researcher used the semistructured interview ${ }^{(18)}$ through an instrument developed by the researcher, composed of closed questions (sociodemographic data) and open questions (focused on the object of study), made to verify health needs and the development of educational gerontotechnology. Also, to confirm the data, the medical records of the elderly were used. The conversation interview ${ }^{(19)}$ occurred without pre-elaborated instruments, in the form of informal conversation to obtain the necessary information and participant unsystematic observation ${ }^{(20)}$ with the objective of knowing more deeply the reality of the participants.

For data collection (identification of health needs), application of gerontotechnology and evaluation of this for practice, four haemodialysis sessions were carried out.

\section{Data analysis}

The data analysis phase had four processes: apprehension, synthesis, theorization and transfer, which occurred in a more or less sequential manner. During the apprehension, the researchers organized the information obtained in their research process through codes: SSIN (semi-structured interview notes), ON (observation notes) and OIN (open interview notes) ${ }^{(17)}$.

After organizing the information, the material was read in order to choose the codes that had the most meaning to proceed with the analysis phase. With the codes defined, they were listed in a table format, definition of pre-categories and assimilation of the data found, ordering them for the synthesis. The theorization process was configured as a "puzzle", which consisted in raising the information obtained to a high level of abstraction ${ }^{(17)}$.

The last phase of analysis represented by the transfer was the possibility to contextualize the results in similar situations with the intention of transferring and socializing them. The authors sought to reflect on the results and conclusions found for the nurse's professional practice with regard to the recognition of health needs for the construction of educational gerontotechnology, aiming at promoting the health of the elderly during haemodialysis treatment.

\section{RESULTS}

The results of the study will be presented first with data on the characterization of the elderly, followed by the emerging health needs (foundation for the creation of gerontotechnology), information on the Game of Attitudes (gerontotechnology developed), repercussion of the application of the game for the elderly in treatment haemodialysis.

Ten elderly people participated in the study, seven women and three men. The mean age of the participants was 70.1 years. Of these, two have six and eight children, with the remainder having less than three children. An old man never went to school, but he can read and write; four have incomplete elementary education; one has incomplete high school; and four, complete higher education; five have caregivers, four of whom are daughters, and one is the spouse.

Regarding comorbidities: six reported having hypertension; one, diabetes; and three, hypertension and diabetes. It was found that five elderly people have been undergoing haemodialysis for almost five years. Individual data indicate the existence of elderly people who underwent haemodialysis ten, seven and five years ago.

In order to identify the health needs of the elderly undergoing haemodialysis, based on the data obtained in the interviews, the codes, sub-themes and themes indicative of the health needs of the elderly were listed as Chart 1. 
Chart 1 - Construction of the themes extracted from the codes found in the interviews with the elderly undergoing haemodialysis, Florianópolis, Santa Catarina, Brazil, 2017

\begin{tabular}{|l|l|l|}
\hline \multicolumn{1}{|c|}{ Codes } & \multicolumn{1}{|c|}{ Subthemes } & \multicolumn{1}{|c|}{ Themes } \\
\hline $\begin{array}{l}\text { Unawareness of the disease/treatment at the beginning } \\
\text { Predisposing pathology } \\
\text { Signs and symptoms }\end{array}$ & $\begin{array}{l}\text { Lack of knowledge about Chronic Kidney } \\
\text { Disease its complications, signs and symptoms }\end{array}$ & $\begin{array}{l}\text { Chronic Kidney Disease } \\
\text { complications and problems }\end{array}$ \\
\hline $\begin{array}{l}\text { Chronicity of disease/Disease without cure } \\
\text { Increase in health care/search for information } \\
\text { Food restrictions/feeding care } \\
\text { Arteriovenous Fistula care }\end{array}$ & $\begin{array}{l}\text { Increased health care after diagnosis and } \\
\text { initiation of treatment }\end{array}$ & Self-care \\
\hline $\begin{array}{l}\text { Treatment suffered / difficulties in treatment } \\
\text { Lack of perspective on possibilities for activities }\end{array}$ & $\begin{array}{l}\text { Suffering and lack of empowerment about their } \\
\text { health and illness process }\end{array}$ & Empowerment \\
\hline $\begin{array}{l}\text { Lack of activities at the reception of haemodialysis } \\
\text { Lack of activities during haemodialysis } \\
\text { Difficulty during activity: Bingo }\end{array}$ & Lack of activities during haemodialysis & Deficit of activities \\
\hline $\begin{array}{l}\text { Use of technologies } \\
\text { Bingo developed by the social worker Nursing care }\end{array}$ & Expansion and new possibilities in nursing care & Health promotion and nursing care \\
\hline Family insertion & Family as part of care & Importance of the family \\
\hline
\end{tabular}

\section{Health needs of the elderly who undergo hemodialytic treatment}

The emerging health needs reported by the elderly undergoing haemodialysis were: CKD complications and problems; Self-care; Empowerment; Deficit of activities; Health promotion and nursing care; Importance of the family. These are essential themes for the development of educational gerontotechnology with a view to promoting the health of these individuals.

Chronic Kidney Disease complications and problems - Many elderly people reported their lack of knowledge about CKD before their diagnosis, as well as the treatment available.

At first, I had doubts, because I didn't know the disease. (ID1)

At first, I didn't know anything, how the treatment was, when it started. (ID4)

The possible complications of the underlying pathologies already coexisting also proved to be unknown by the participants.

I already had diabetes and high blood pressure, and the doctor told me to do my treatment, take care of myself and no, I did it, started it and abandoned it, if I knew it could happen I would have taken care of myself more. [...] (ID 4)

In addition to the lack of knowledge about the possible complications of the underlying pathologies (hypertension and diabetes), the signs and symptoms before their diagnosis of CKD were also not valued by them, so that the search for health services only occurred when the disease was practically installed, or when the signs and symptoms were more exacerbated. The late search for care may have occurred due to the lack of knowledge and severity of CKD by these individuals.

[...] when I was no longer urinating and getting very heavy, very swollen. (ID1)

I felt tired, tired [...] then when I went to do my exams everything had changed. (ID8)
Self-care - There were difficulties in starting treatment, mainly in the diagnosis received by the elderly, ignorance of the disease, imposed treatment and dietary and social restrictions.

I know my disease has no cure, today I know I have to take care of myself. (ID1)

The need for increased care aroused great interest in the elderly in seeking information about their disease and treatment. In this way, both health professionals assisted in the learning process and other sources of information served to search for knowledge, one of them being the internet.

When in doubt, I ask the professionals, when I don't know, I go to Google, Ilearned to use the internet, my daughter taught me [...] (ID6)

The increased demand for information about their diagnosis and treatment may be related to the high amount of restrictions that this individual has in this new condition imposed on their life. Changing life habits is a challenge/need to be faced.

The most difficult thing is food, sometimes I am very hungry, and now with the summer coming I spend a lot of time working, I feel very thirsty and I know that I cannot drink a lot of water because it is restricted. (ID3)

The elderly reported having started care after diagnosis, especially with food, highlighting preparation, reducing salt consumption and replacing it with natural spices, cooking time. Address the importance of information from health professionals, assisting them in food choices and preparation.

[...] meal, I don't eat it with salt, I mix seasonings to put in the food and so far everything has worked out. (ID6)

Regarding care with the AVF, few elderly people reported specific care.

I don't take more than $5 \mathrm{~kg}$ in my arm, I do exercise with the balls to improve the fistula from time to time. (ID6) 
This data reflects the relevance of nursing care aimed at preventing and promoting the health of these individuals during haemodialysis, enabling empowerment to live their condition with quality.

Empowerment - Haemodialysis imposes an exhausting routine for the elderly, influencing their way of life.

[...] at the beginning, it's a very painful treatment, we don't know anything, when we sit here, we find out, because there are days here that we are fine, but there are days here that we get bad. (ID8)

Nursing care for the elderly undergoing haemodialysis must pass through the techniques, covering the complexity of care and of each human being. Thus, inserting educational activities in this field of work emerges as a possibility of care and health promotion, stimulating empowerment for self-care.

Due to the physical limitations that the treatment imposes on the elderly, they do not believe in new possibilities, such as activities to be performed during haemodialysis to improve their perception of the disease and treatment, improve the quality of life and self-esteem.

If I had something to do, I would do it, one more thing for us to participate in, but there is nothing, right. (ID2)

Providing information, educating individuals, empowering the elderly to encourage self-care actions is challenging for nursing professionals, since they have a primary role in this context of health care.

Deficit of activities - The elderly remain in the haemodialysis unit for long periods, on average three to four hours for at least three times a week. They stay at the institution's reception waiting for treatment to start or waiting for transport to return to their homes.

When I arrive at the reception, I am talking to the people there who are waiting. (ID5)

Despite being in activities involving health actions for so long, practices are restricted to punctual care. Nursing care is mainly linked to the direct assistance of techniques, such as weighing, puncture of the arteriovenous fistula (AVF), control and monitoring of the signs and symptoms of individuals, care in the face of complications, among others. No educational activity performed by nursing was carried out, or mentioned by the participants during the data collection period, but there was a demonstration of their interest in these actions.

If I had something to do, I would do it, one more thing for us to participate in, but there is nothing... right. (ID2)

Health promotion and nursing care - Nursing professionals received praise from the elderly, especially in relation to good contact, showing satisfaction and recognition for the care provided.

Here they take care of us very well, as I told you they put us in the machine here, then they give us a snack, if we need something for them they give it, a blanket, or a stool to put our feet on. (ID9)
The use of technologies was cited by the elderly as a tool for distraction and decreased perception of haemodialysis time. In their view, nursing care has become restricted only to procedures.

Here only what I see is the television, if stands it in front of me I look there ... when I look, time passes. (ID5)

Sometimes I bring a book, I read, I like to read, I listen to music. (ID3)

Importance of the family - Regarding family participation, members were mentioned by the elderly as those who help and collaborate in their treatment, being recognized/important for carrying out some activities, especially domestic ones.

My daughter does most of the things, because I can't put clothes out to dry. (ID2)

Elderly patients on haemodialysis usually have some physical restrictions that prevent them from performing daily activities. In this sense, family members assume an important role in terms of assistance and continuity of care for the elderly undergoing haemodialysis at home. In addition, they help with accessibility to health services, as they are the ones who bring the elderly to haemodialysis sessions.

My husband brings me, he waits in the car until he finishes, he helps me. (ID7)

\section{Creation of gerontotechnology: the attitudes game}

It is believed that the creation of gerontotechnology should be aligned with the needs of the public for which it is projected and be based on the emerging needs of the elderly undergoing haemodialysis (Complications and aggravations of CKD; Selfcare; Empowerment; Deficit of activities; Health promotion and Nursing care; Importance of the family).

With the recognition of health needs, an educational gerontotechnology entitled Game of Attitudes was created. It is a card game with the objective of enabling the understanding of the elderly about the influence of their attitudes on the current health condition and quality of life.

The Game of Attitudes is filed for patent registration n' RPI00097. It consists of 40 cards: 20 green cards inferring positive attitudes and 20 red cards with negative attitudes, which should be "adopted" or "avoided" by the chronic renal patients undergoing haemodialysis. In addition, there is a die with six faces: green, red and black. When rolling it, the card must be chosen in the respective color that the die presents, emphasizing that the black color indicates the possibility of "stealing" the opponent's card. The green cards represent appropriate actions, which indicate"go ahead" and "continue"; the red color involves actions that must be rethought, representing behaviors related to "stop" and "attention".

The game can be applied to pairs or more participants. Each player, when rolling the dice, must remove a card corresponding to the color that falls. Wins the one who gets the most green cards at the end. The cards have a size of $13.7 \mathrm{~cm} \times 9.1 \mathrm{~cm}$ (in order to meet the specificities and physical limitations presented by the elderly, facilitating handling, in addition to providing sufficient space for illustrations and text). 
In each letter, there are two texts: one written in larger size (upper part of the letter), which corresponds to the attitude; and, below, another text (bottom of the letter) referring to the consequence and related illustrations. After making the 40 letters, the material was sent to an expert (nephrologist nurse with experience in haemodialysis) for suggestions and collaborations regarding the content presented, illustrations and appearance. Afterwards, the letters were covered with contact paper (allowing asepsis of the material before and after departure). The game was applied between researcher and patient individually, with an average of 40 minutes each session. During the activity, the time of the elderly was respected, according to the need presented in each condition, including there being short stops to check blood pressure and snack.
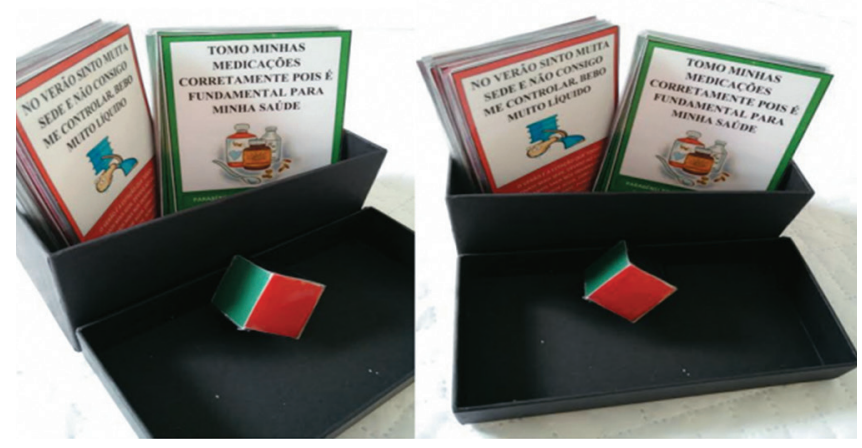

Figure 1 - illustrative photo of the Game of Attitudes

\section{Development of the attitudes game}

To identify the results with the application of educational gerontotechnology entitled Game of Attitudes and based on testimonies, codes were identified, pre-categories were defined, classifying them into sub-themes and themes. The following themes emerged: overcoming, occupation and knowledge (as shown in Chart 2).

Chart 2 - Definition of subthemes and themes based on the codes generated in the interviews after the application of educational gerontotechnology "Game of Attitudes"

\begin{tabular}{|l|l|l|}
\hline \multicolumn{1}{|c|}{ Codes } & \multicolumn{1}{c|}{ Subthemes } & \multicolumn{1}{c|}{ Themes } \\
\hline $\begin{array}{l}\text { This one I managed to } \\
\text { play/Learning to play }\end{array}$ & $\begin{array}{l}\text { Learning and } \\
\text { achievement }\end{array}$ & Overcoming \\
\hline $\begin{array}{l}\text { Help us/Occupy your head/ } \\
\text { relieve your thoughts/l like } \\
\text { it because we keep doing } \\
\text { something/the session } \\
\text { goes by quickly }\end{array}$ & $\begin{array}{l}\text { Feeling at ease during } \\
\text { the session/Feeling of } \\
\text { well-being/Distraction } \\
\text { during the session }\end{array}$ & Occupation \\
\hline Learning from the game & $\begin{array}{l}\text { Learning/Educational } \\
\text { technology }\end{array}$ & Knowledge \\
\hline
\end{tabular}

Overcoming - Overcoming has emerged among the elderly since the beginning of the game. The demonstration of being able to achieve, accomplish, and materialize something was remarkable during the activity performed.

I learned how to play this game, it was good to participate like this on my own, to pick it up and play, you know... I managed to be like that. (ID5)
[...] I liked it, I can play it, I thought it would disturb me, but it didn't ... (ID1)

It was not difficult, I didn't think it was possible, but it did [laughs] ... I can do it, I don't believe it [laughs] ... (ID5)

Occupation - The elderly participants in the study reported that the insertion of the game brought occupation and distraction during the haemodialysis session, a treatment that is sometimes considered monotonous and long-lasting, since the deficit of activities during haemodialysis sessions is present.

I thought it helps us here during the session [...] it's a different thing, it helps to pass the time, when you see it is over [...] it passed quickly, and this is a different thing for us to do here. (ID4)

Good, because I didn't even sleep anymore... you saw it [laughs] and now it's my time. (ID6)

It was good because I don't do anything here. We occupy our heads, and time passes here, it's almost time for me to finish, that's it for today... just wait for the city hall car to pick me up. (ID2)

In addition to occupying time, negative feelings were mitigated during the practice of the Game of Attitudes, as well as the feeling of well-being during the educational practice.

It helped to forget a little of what I was feeling, because when we stay here, like that, standing still, we keep thinking about the bad things, the problems. (ID1)

For me today it was very good, you came here and brought this, I'm even more relieved of my head today, I will leave, feeling happy. (ID8)

The experience was good yes, very good... working our head, even though I was feeling kind of down like that. (ID3)

Knowledge - The game enabled knowledge on the part of the elderly. There were reports of comparisons with actions that were previously taken and that now generate reflections in the face of new possibilities and attitudes.

There is something that talks about the family there and it is true, at the beginning I didn't want to... they would find out what it was all about, but then you see that they help it gets a little easier. (ID4)

Taking care is very important, we always learn something [...] it was very good, I liked it, it passed quickly... I learned about avocado, I will reduce it. (ID6)

The game enabled the elderly to recognize the complexity and importance of care covering comprehensiveness, as well as to recognize themselves as subjects capable of changing and creating a new perspective and improving quality of life.

e saw the importance of the medicine, the medication, our food, all right to be well [...] my daughter is helping, she accompanies me, what we read in the letter too, the family being with us helps us people, alone I can't. (ID8)

Everything we take care of and do is to get well and better [...] this game makes us think about the things we do ... what is right and what is wrong. (ID9) 


\section{DISCUSSION}

CKD is silent and, for this reason, is often detected late; when reaching its most advanced stage, it is necessary to carry out some type of renal replacement therapy, especially haemodialysis ${ }^{(21)}$. Experiencing haemodialysis treatment exposes elderly people with CKD to live daily with a disease that requires long-term treatment, may exist with complications and limitations in their daily lives, in addition to biopsychosocial losses and changes that interfere with their quality of life ${ }^{(22)}$.

The nursing team, having direct contact with these elderly people, has the possibility to prioritize innovative alternatives to exercise care. To this end, inserting new methods and technologies emerges as an innovative challenge for health promotion in this context ${ }^{(21)}$. Such actions provide transformations in daily practices, which should be valued/achieved by nursing professionals.

It is emphasized that the long stay of the elderly in haemodialysis therapy as well as the various changes in habits and care for prevention and health promotion instigate and provide nursing care as a stimulus for the empowerment of these individuals, a community development strategy that aims to increase power and autonomy in order to direct their own destinies ${ }^{(23)}$. In this context, the insertion of playful educational actions is a relevant strategy, mainly due to the low level of education of the elderly. The population with the highest illiteracy rate is people aged 60 or over, corresponding to the percentage of $24.4 \%{ }^{(21)}$.

The nursing team can offer ways that facilitate the understanding of the health condition and illness, developing co-participation, self-responsibility, behavior change in relation to lifestyle as well as production of hope and perseverance that promote their adaptation to treatment and improvement of well-being and quality of life. Elderly people with CKD should not be limited to traditional treatment; it is necessary to include their needs as a priority for treatment, as well as life experiences, encouraging the remodelling of daily living ${ }^{(24)}$.

The scientific concern focused on educational gerontotechnologies is worldwide, as aging presents challenges. For this reason, countries need to design and implement sustainable policies for local aging, in line with the needs of the elderly, with home care services to improve their well-being and inclusion in society ${ }^{(25)}$. Thus, this theme can be considered as an instrumentalizing source of nursing care, due to its emerging relevance in the context of the elderly's health as well as the scarcity of works on the theme and the lack of its dissemination in the Brazilian nursing literature, constituting itself as a gap in knowledge and challenge ${ }^{(13)}$. Health education with patients during haemodialysis allows knowledge about their condition, encouraging safety and subsidies for their self-care, in addition to optimizing the time of the haemodialysis session with learning.

The insertion of gerontotechnology is still challenging, as it is a recent and innovative theme, however it brings a new way of looking at the care process, regardless of its field of action; can be an instrument that complements care in the areas of geriatrics and gerontology, providing transformations in daily practices ${ }^{(26)}$.

Thus, the construction and appropriation of new knowledge, aiming to guide alternative paths, based on the needs of the person's care and in the search for the promotion of their wellbeing ${ }^{(27)}$, are essential for living on haemodialysis. In this context, the educational game stimulates psychological, social and cognitive development, it is a natural and motivating activity, it provides intrinsic strengthening and the desire to learn content on its own. The insertion of this technology values the elderly with chronic kidney through cooperation with the nursing team, valuing their own life, highlighting the fact of assuming their responsibilities, adhering to the treatment and fulfilling their obligations ${ }^{(28)}$.

The application of the Game of Attitudes instilled feelings of overcoming in the elderly, recognized as the improvement that the person can experience in their personal qualities ${ }^{(29)}$. Feelings of occupation and knowledge also emerged; and, in this line, the use of educational gerontotechnology during the haemodialysis session enables the development of care actions in the routine of haemodialysis, which permeate the clinic environment, entering the residence of the elderly through reflection, knowledge and guidance of new educational practices.

It is noteworthy that crossing the clinic environments and involving the home/family in the care of the elderly undergoing haemodialysis is essential for successful treatment ${ }^{(22)}$. Thus, the involvement of the family to learn about the health condition and illness of their family member is extremely important ${ }^{(30)}$. The Game of Attitudes can be used not only in the context of the clinic, but also at home and with families.

\section{Study limitations}

As study limitations, research stands out in a unique reality, which may be influenced by the characteristics of the population, as well as the emerging care needs.

\section{Contributions to the area of Nursing, Health or Public Policy}

This work contributes to nursing by stimulating innovation in care and change in nursing care practice. The improvement of instrumental strategies for care enables changes in daily practices, (re)modelling care practices for both the elderly and professionals. Educational gerontotechnologies can be a new way of offering care; they are tools that enrich daily life, transcending techniques and procedures provided, challenge the change in care practice and emerge as a possibility for innovation to promote the health of the elderly.

\section{FINAL CONSIDERATIONS}

The recognition of the health needs of the elderly undergoing haemodialysis provided important data for the construction and development of educational gerontotechnology, allowing the professional nurse to develop care methodologies related to the real needs of the elderly. The application of "Game of Attitudes" gerontotechnology enabled the promotion of the health of the elderly undergoing haemodialysis by reflecting on their perceptions and practices, occupation/entertainment during haemodialysis sessions and the construction of empowering knowledge for self-care. 


\section{REFERENCES}

1. Instituto Brasileiro de Geografia e Estatística (IBGE). Resultados do Censo 2010: Ministério do Planejamento, Orçamento e Gestão. Diretoria de Pesquisas. Coordenação de População e Indicadores Sociais [Internet]. 2010. [cited 2016 Apr 07]. Available from: http://www.censo2010. ibge.gov.br/resultados_do_censo2010,php

2. Oliveira IG, Ziede M, Pegoraro Rocha RER. Population aging of a municipality of the Catarinense Middle West. Revista Interdisciplinar de Estudos em Saúde, Caçador. [Internet]. 2017 [cited 2019 Feb 10];6(2):11-22. Available from: http://dx.doi.org/10.33362/ries.v6i2.1392

3. Rosa KR, Loures MC. Qualidade de vida de idosos em hemodiálise: enfermagem e o lúdico. Estudos [Internet]. 2013[cited 2016 Apr 06];40(4):419-46. Available from: http://tede2.pucgoias.edu.br/index.php/estudos/article/view/3050/1851

4. Park Jl, Baek H, Jung HH. Prevalence of chronic kidney disease in Korea: the Korean National Health and Nutritional Examination Survey 2011-2013. J Korean Med Sci. 2016;31(6):915-23. doi: 10.3346/jkms.2016.31.6.915

5. Collins AJ, Foley RN, Gilbertson DT, Chen S-C. United States Renal Data System public health surveillance of chronic kidney disease and endstage renal disease. Kidney Int Suppl. 2015;5(1):2-7. doi: 10.1038/kisup.2015.2

6. Francis ER, Kuo CC, Bernabe-Ortiz A, Nessel L, Gilman RH, Checkley W, et al. Burden of chronic kidney disease in resource-limited settings from Peru: a population-based study. BMC Nephrol. 2015;16:114. doi: 10.1186/s12882-015-0104-7

7. Ene-lordache B, Perico N, Bikbov B, Carminati S, Remuzzi A, Perna A, et al. Chronic kidney disease and cardiovascular risk in six regions of the world (ISN-KDDC): a cross-sectional study. Lancet Glob Health. 2016;4(5):e307- 19. doi: 10.1016/S2214-109X(16)00071-1

8. Marinho AWGB, Penha AP, Silva MT, Galvão TF. Prevalência de doença renal crônica em adultos no Brasil: revisão sistemática da literatura. Cad Saúde Colet. 2017;25(3):379-88. doi: 10.1590/1414-462×201700030134

9. Machado FS, Vianna LG, Coelho KHV, Oliveira MLC, Faleiros, et al. Quality of life of elderly submitted hemodialysis: a systematic review. Rev Kairós Gerontol [Internet]. 2014 [cited 2019 Feb 07];17(3):149-63. Available from: https://revistas.pucsp.br/index.php/kairos/article/ viewFile/21914/16111

10. Takemoto AY, Okubo P, Bedendo J, Carreira L. Evaluation of quality of life in elderly undergoing hemodialysis. Rev Gaúcha Enferm. 2011;32(2):256-62. doi: 10.1590/S1983-14472011000200007

11. Organização Mundial da Saúde. A Carta Otawa para a promoção da saúde. In: Organizacion Panamericana de la Salud. Promoção de la salud: una antologia. Publicacion Cientifica n. 557. Washington, DC, Estados Unidos da América, OPS, 1996: 367-372.

12. Ministério da Saúde (BR). Secretaria de Vigilância em Saúde. Secretaria de Atenção à Saúde. Política Nacional de Promoção da Saúde. 3. ed. Brasília : Ministério da Saúde, 2010.

13. Hammerschmidt KSA, Lenardt MH. Innovative educational technology for empowering the elderly with diabetes mellitus. Texto Contexto Enferm. 2010;19(2):358-65. doi: 10.1590/S0104-07072010000200018

14. Carleto DG, Santana CS. Intergerational relations mediated by the digital Technologies. Rev Kairós Gerontol [Internet]. 2017 [cited 2019 Feb 07];20(01):73-91. Available from: https://revistas.pucsp.br/index.php/kairos/article/viewFile/31907/22128

15. Hammerschmidt KSA, et al. Cuidado de Enfermagem: Interfaces teóricas e práticas no ciclo vital do ser humano. Curitiba: Crv, 2015. 384 p.

16. Berardinelli LMM, Guedes NAC, Ramos JP, Nascimento e Silva MG. Educational technology as a strategy for the empowerment of people with chronic illnesses. Rev Enferm UERJ [Internet]. 2014 [cited 2019 Feb 07];22(05):603-9. Available from: http://www.facenf.uerj.br/v22n5/v22n5a04.pdf

17. Trentini M, Paim L, Silva DMGV. Pesquisa Convergente-Assistencial - PCA: delineamento provocador de mudanças nas práticas de saúde. $3^{3}$ ed. Porto Alegre: Moriá; 2014.

18. Minayo MCS. O desafio do conhecimento: pesquisa qualitativa em saúde. 14a ed. São Paulo: Hucitec-Abrasco; 2013.

19. Lenardt MH, Hammerschmidt KSA, Modesto AP, Borghi ACS. O sistema de conhecimento e de cuidado dos idosos em hemodiálise concernente a terapia medicamentosa. Cogitare Enferm [Internet]. 2008[cited 2016 Apr 06];13(2):165-172. Available from: http://revistas. ufpr.br/cogitare/article/view/12432/8547

20. Spradley JP. Participant observation. New York: Holt, Rinehart and Winston 2 a ed. 1980.

21. Ministério da Saúde (BR). Departamento da Atenção Básica. Envelhecimento e Saúde da pessoa idosa [Internet]. Ministério da Saúde (Séria A. Normas e Manuais Técnicos - Cadernos de Atenção Básica - n. 19). 2006 [cited 2016 Apr 06]. 187 p. Available from: http://189.28.128.100/ dab/docs/publicacoes/cadernos_ab/abcad19.pdf

22. Carvalho JÁ, Escobar KAA. Cuidador de Idosos: um estudo sobre o perfil dos cuidadores de idosos do programa de assistência domiciliar (PAD) da associação dos aposentados e pensionistas de Volta Redonda - AAP-VR. Rev Científ Itpac[lnternet]. 2015 [cited 2016 May 03];8(1):1-13. Available from: https://www.itpac.br/arquivos/Revista/76/Artigo_6.pdf

23. Quintana JM, Hammershmidt KSA, Santos SSC. Perception of older adults who received nursing care during hemodialysis. Rev Eletron Enferm[Internet]. 2011 [cited 2016 Sep 03];16(3):662-70. Available from: https://www.fen.ufg.br/fen_revista/v16/n3/pdf/v16n3a22.pdf

24. Silva RAR, Souza NVL, Oliveira GJN, Silva BCO, Rocha CCT, Holanda JRR. Coping strategies used by chronic renal failure patients on hemodialysis. Esc Anna Nery [Internet]. 2016 [cited 2016 Sep 03];20(1):147-154. Available from: http://www.scielo.br/pdf/ean/v20n1/14148145-ean-20-01-0147.pdf 
25. Atarodi S, Berardi AM, Toniolo AM. Comparação de práticas de políticas locais para implementar serviços de atendimento domiciliar baseados em TIC para envelhecimento na Finlândia, França, Itália, Espanha e Suécia. Gerontechnol.;18(2):108-21. doi: 10.4017/ gt.2019.18.2.005.00

26. Ferreira JM, Hammerschmitdt KSA, Siewert JS, Alvarez AM, Locks MOH, Heidmann ITSB. Gerontotechnology for the prevention of falls of the elderly with Parkinson. Rev Bras Enferm. 2019;72(Suppl 2):243-50. doi: 10.1590/0034-7167-2018-0704

27. Xavier BLS, Santos I, Almeida RF, Clos AC, Santos MT. Individual and clinical characteristics of clients with chronic kidney disease on renal replacement therapy. Rev Enferm UERJ [Internet]. 2014 [cited 2016 Sep 03];22(3):314-20. Available from: http://www.facenf.uerj.br/v22n3/ v22n3a04.pdf

28. Prezotto KH, Abreu IS. The chronic renal patient and the adherence to hemodialysis treatment. Rev Enferm UFPE[Internet]. 2014 [cited 2016 Sep 03];8(3):600-5. Available from: https://periodicos.ufpe.br/revistas/revistaenfermagem/article/viewFile/9715/9794

29. Ucha F. Que conceito: superação [Internet]. 2015[cited 2016 May 03] Available from: http://queconceito.com.br/superacao

30. Brum AKR, Camacho Alessandra CLF, Valente GSC, Sá SPC, Lindolpho MC, Louredo DS. Program for caregivers of elderly patients with dementia: experience report. Rev Bras Enferm [Internet]. 2013 [cited 2016 May 03];66(4):619-24. Available from: http://www.scielo.br/pdf/ reben/v66n4/v66n4a25 x 